\title{
CEBPA wt Allele
}

National Cancer Institute

\section{Source}

National Cancer Institute. CEBPA wt Allele. NCI Thesaurus. Code C52525.

Human CEBPA wild-type allele is located in the vicinity of 19q13.1 and is approximately 2 $\mathrm{kb}$ in length. This allele, which encodes CCAAT/enhancer-binding protein alpha, is involved in transcriptional enhancement. 